\title{
QUEIJOS ARTESANAIS: QUALIDADE FÍSICO-QUÍMICA E MICROBIOLÓGICA E AVALIAÇÃO DAS CONDIÇÕES HIGIENICO- SANITÁRIAS DOS MANIPULADORES E AMBIENTE DE PRODUÇÃO
}

\author{
Gabriela Rigueira Miranda ${ }^{1}$ \\ Ana Márcia Souza ${ }^{2}$ \\ Aurélia Dornelas de Oliveira Martins ${ }^{3}$ \\ Elaine Souza Cocaro ${ }^{4}$ \\ José Manoel Martins ${ }^{5}$
}

\section{RESUMO}

A produção de queijos a partir de leite cru é uma atividade tradicional nos municípios de Minas Gerais. O presente estudo objetivou avaliar as boas práticas de fabricação na produção de queijos artesanais em Teixeiras-MG. Foram coletadas amostras de leite cru e queijo Minas artesanal de três propriedades. As amostras foram avaliadas quanto as características físico-químicas e microbiológicas. Em quatro agroindústrias familiares foram analisadas superfícies de produção, mãos do ordenhador e manipulador e caixa de transporte pela técnica do swab, bem como realizadas análises microbiológicas dos ambientes de produção e geladeira. Das amostras avaliadas, as análises de aeróbios mesófilos do leite cru refrigerado apresentaram valores acima dos exigidos pela legislação. Acidez e proteína do leite de duas propriedades apresentaram valores não conformes com a legislação vigente. Todas as amostras de queijo apresentaram valores de coliformes conforme estabelecido pela legislação vigente. Contagens de aeróbios mesófilos, coliformes a $30^{\circ} \mathrm{C}$ e $45^{\circ} \mathrm{C}$ e bolores e leveduras apresentaram valores superiores nas mãos do ordenhador quando comparado ao manipulador de alimentos. Conclui-se a importância das boas práticas de fabricação na produção do queijo, assim como a qualidade da matériaprima para que o produto final seja seguro do ponto de vista microbiológico.

Palavras-chave: agroindústria familiar, boas práticas de fabricação, segurança dos alimentos.

\footnotetext{
1 Graduada em Tecnologia de Laticínios (IF Sudeste MG, campus Rio Pomba). E-mail: gabilaticinios@yahoo.com.br

Graduada em Tecnologia de Laticínios (IF Sudeste MG, campus Rio Pomba). E-mail: anamarciadesouza.laticinios@gmail.com

${ }^{3}$ Graduada em Ciência e Tecnologia de Laticínios (UFV). Doutora em Ciência e Tecnologia de Alimentos (UFV). Professora do Departamento de Ciência e Tecnologia de Alimentos (IF Sudeste MG, campus Rio Pomba). E-mail: aurelia.dornelas@ifsudestemg.edu.br

${ }^{4}$ Graduada em Nutrição (UFV). Mestre em Ciências (UNIFESP). Nutricionista (IF Sudeste MG, campus Rio Pomba). E-mail: elaine.cocaro@ifsudestemg.edu.br

${ }^{5}$ Graduado em Ciência e Tecnologia de Laticínios (UFV). Doutor em Ciência e Tecnologia de Alimentos (UFV). Professora do Departamento de Ciência e Tecnologia de Alimentos (IF Sudeste MG, campus Rio Pomba). E-mail: jose.manoel@ifsudestemg.edu.br
} 


\title{
ARTESAN CHEESE : PHYSICAL CHEMICAL AND MICROBIOLOGICAL QUALITY AND EVALUATION OF SANITARY CONDITIONS OF HANDLERS AND PRODUCTION ENVIRONMENT
}

\begin{abstract}
The production of cheese from raw milk is a traditional activity in the municipalities of Minas Gerais. This study aimed to evaluate the good manufacturing practices in the production of artisan cheeses in Teixeiras-MG. Samples of raw milk and cheese artisanal Minas three properties which were analyzed for physico-chemical and microbiological characteristics were collected. In four family farms were evaluated surfaces production, milker's hands and handler and kennel by the swab technique and microbiological analysis of production and refrigerator environments. Of the samples, the analyzes of aerobic mesophilic refrigerated raw milk had levels higher than those required by law. Acidity and protein of milk had two properties not complying values with current legislation. All cheese samples showed coliform values as established by law. Counts of aerobic mesophilic, coliforms at $30^{\circ} \mathrm{C}$ and $45^{\circ} \mathrm{C}$ and molds and yeasts showed higher values in the hands of the milker when compared to the food handler. It follows the importance of good manufacturing practices in the production of cheese, as well as the quality of the raw material so that the final product is safe from a microbiological point of view.
\end{abstract}

Key words: family agribusiness, food safety, Good Manufacturing Practices.

\section{INTRODUÇÃO}

O Estado de Minas Gerais é reconhecido nacionalmente pela sua tradição na produção de queijos, conhecidos como queijos de Minas, que representam para o estado tanto uma importância econômica quanto sociocultural (BRASIL, 2001). Entende-se por queijo Minas Artesanal o queijo elaborado, na propriedade de origem do leite, a partir do leite cru, hígido, integral e recém-ordenhado, utilizando-se na sua coagulação somente a quimosina de bezerro pura e no ato da prensagem somente 0 processo manual, e que o produto final apresente consistência firme, cor e sabor próprios, massa uniforme, isenta de corantes e conservantes, com ou sem olhaduras mecânicas, conforme a tradição histórica e cultural da região do Estado onde for produzido (LEI ESTADUAL/MG, 2002). Devido seu alto teor de umidade e de ser manipulado, apresenta condições propícias a contaminação, sobrevivência e multiplicação bacteriana, podendo estas bactérias ser patogênicas ou produzir metabólitos microbianos causadores de intoxicações e/ou infecções alimentares nos seres humanos (CÂMARA et al., 2000).

De acordo com a EMATER-MG (2014), as seis regiões produtoras de queijo Minas Artesanal (Serro, Canastra, Araxá, Campos das Vertentes, Cerrado e Triângulo Mineiro) possuem 9.789 produtores, que são responsáveis por uma produção de cerca de 29.897 toneladas de queijo por ano. O reconhecimento dessas regiões é respaldado por estudos do processo de fabricação, em cada região, tendo em vista características peculiares do local de origem, tais como: história, economia, cultura e clima, entre outros itens.

O estudo da agricultura familiar como indutora do desenvolvimento econômico vem ganhando mais espaço nos últimos anos devido ao impulso gerado pela ampliação da discussão sobre o desenvolvimento sustentável, geração de 
emprego e renda, segurança alimentar e o potencial de gerar desenvolvimento para regiões menos favorecidas (SOUZA, 2010). Estudos realizados por Mattos e Santana (2014) ao avaliarem agricultores familiares do sudeste do estado do Pará mostram que $47 \%$ das agroindústrias leiteiras avaliadas produziam até 50 litros/dia de leite e $53 \%$ entre 51 e 100 litros/dia. Segundo os autores, cada estabelecimento empregava, em média, 1,46 trabalhadores, contra 1,40 no início da atividade. Siqueira et al. (2013) observaram uma grande variedade de alimentos produzidos pelos agricultores familiares de Alegre-ES, totalizando 46 diferentes alimentos voltados aos mercados locais, dentre eles encontra-se o iogurte (120 g) cuja oferta é de $720 \mathrm{~kg} / \mathrm{mês}$.

Existem cerca de 30.000 agroindústrias no estado de Minas Gerais relacionadas à produção de queijo Minas Artesanal. O modo de produção do queijo de leite cru nas serras de Minas Gerais constitui um conhecimento tradicional e um traço marcante da identidade cultural das regiões produtoras (IMA, 2014). Soares, Silveira e Fialho (2010) relatam que em geral, as políticas agrícolas brasileiras recorrentemente têm penalizado o setor primário e por decorrência os atores que nele operam, sobretudo aqueles atores menos favorecidos, proprietários de áreas mais restritas, os quais vêm, sistematicamente, padecendo e experimentando um dilema, no sentido de, ou abandonar a atividade que efetivamente conhecem e que os identifica, ou tentar, permanecer em tal atividade, inobstante às dificuldades encontradas.

Por outro lado, o município de Teixeiras é localizado na Zona da Mata de Minas Gerais e integra, geograficamente, à microrregião de Viçosa. O seu território corresponde a uma área de $167 \mathrm{~km}^{2}$. Sua população é de 11.355 habitantes (IBGE, 2014). A economia do município é baseada na zona rural. As principais atividades econômicas desenvolvidas no município são: agricultura (café, arroz, feijão, mandioca, milho, abacaxi, tomate, cana-de-açúcar, batata-doce), pecuária (bovinocultura e suinocultura), silvicultura e exploração florestal, além da produção de queijos nas agroindústrias familiares.

Via de regra, a legislação brasileira não permite a comercialização de queijos de leite cru com menos de 60 dias de maturação. Com a publicação da IN no 30/2013 (BRASIL, 2013), o queijo artesanal maturado em período inferior a 60 dias, poderá ser comercializado por todo País, desde que a queijaria esteja formalizada, o que não é o caso da maioria dos estabelecimentos produtores de queijos artesanais no Brasil. Além de expandir os requisitos de certificação de queijarias, a norma flexibiliza a análise de estudos técnico-científicos que comprovem que a redução do período de maturação não compromete a qualidade e a inocuidade do produto (BRASIL, 2013). O produtor de queijo artesanal interessado em comercializar seus produtos deve implantar Programa de Controle de Mastite com a realização de exames para detecção da doença, incluindo análise periódica do leite da propriedade em laboratório da Rede Brasileira da Qualidade do Leite (BRASIL, 2013).

Diante do exposto, o presente estudo tem por objetivo avaliar as boas práticas de fabricação na produção de queijos artesanais do município de TeixeirasMG e as condições do produto no processo de comercialização.

\section{MATERIAL E MÉTODOS}

As análises microbiológicas de mãos de ordenhadores e manipuladores, caixas de transporte e ambiente de produção dos queijos foram realizadas em quatro agroindústrias do município de Teixeiras. As amostras do leite cru e dos queijos artesanais foram coletadas de três agroindústrias, sendo que uma não 
permitiu a coletas de tais amostras. Para análise do leite cru, foram coletadas sete amostras de cada agroindústria analisada, totalizando 21 amostras.

Nas agroindústrias avaliadas, a ordenha era manual e os produtos não eram inspecionados por órgãos competentes, sendo os queijos artesanais comercializados apenas no município de Teixeiras.

Imediatamente após a coleta, as amostras foram transportadas aos Laboratórios de Físico-química e de Microbiologia do Departamento de Ciência e Tecnologia de Alimentos do Instituto Federal de Educação, Ciência e Tecnologia do Sudeste de Minas Gerais, Campus Rio Pomba (IF Sudeste MG-Campus Rio Pomba).

\subsection{Análises do leite cru utilizado na produção dos queijos}

Amostras de leite cru foram coletadas em frascos estéreis, transportadas aos laboratórios sob refrigeração e submetidas à análise microbiológica de aeróbios mesófilos (APHA, 2001) e análises físico-químicas de acidez titulável, gordura, umidade, cloretos, $\mathrm{pH}$, extrato seco total, extrato seco desengordurado, cinzas e densidade (BRASIL, 2006) e proteína pelo método do formol (SILVA et al., 1997). As análises foram feitas em duplicata e apenas uma repetição.

\subsection{Análise dos queijos artesanais}

Os queijos, já embalados, foram coletados diretamente da propriedade rural, mantidos sob refrigeração e imediatamente transportadas aos laboratórios para análises microbiológicas de coliformes $30^{\circ} \mathrm{C}$ e $45^{\circ} \mathrm{C}$ (BRASIL, 2003) e físicoquímicas de acidez titulável, gordura, umidade, cloretos, $\mathrm{pH}$, extrato seco total, extrato seco desengordurado e cinzas (BRASIL, 2006).

\subsection{Avaliação das condições higiênico-sanitárias dos manipuladores e ordenhadores}

Foram realizadas análises microbiológicas das mãos do manipulador e mãos do ordenhador logo após a higienização das mesmas por meio da técnica do swab, conforme descrito por Andrade (2008). Os tubos refrigerados foram transportados ao laboratório para realização das análises de coliformes $30^{\circ}$ e $45^{\circ} \mathrm{C}$, aeróbios mesófilos e bolores e leveduras (BRASIL, 2003).

\subsection{Avaliação das condições higiênico-sanitárias das caixas de transporte e ambiente de produção}

Para a análise microbiológica da caixa de transporte e da bancada de produção, o swab foi umedecido em $10 \mathrm{~mL}$ de solução tampão fosfato, coletando a amostra usando o molde de $50 \mathrm{~cm}^{2}$, após, o swab foi colocado na solução e realizou-se agitação (ANDRADE, 2008). As amostras foram mantidas refrigeradas e transportadas ao laboratório para análises de aeróbios mesófilos e bolores e leveduras (BRASIL, 2003).

Para o ambiente (em cima da geladeira e próximo a bancada de produção) foram realizadas análises microbiológicas por meio da técnica de sedimentação simples (APHA, 2001). As amostras foram avaliadas quanto a contagem de aeróbios mesófilos e bolores e leveduras conforme Brasil (2003). 


\subsection{Análise dos resultados}

Os resultados foram submetidos a análise de variância e as médias comparadas pelo teste de Tukey ao nível de $5 \%$ de probabilidade, utilizando-se o programa estatística SISVAR (FERREIRA, 2003).

\section{RESULTADOS E DISCUSSÕES}

\subsection{Análises do leite cru utilizado na produção dos queijos}

A maioria das análises físico-químicas do leite cru refrigerado (Tabela 1) estão de acordo com o preconizado pela legislação, exceto acidez dos leites das agroindústrias $\mathrm{A}$ e $\mathrm{C}$ e proteína dos leites das agroindústrias $\mathrm{A}$ e $\mathrm{B}$.

\begin{tabular}{|c|c|c|c|c|}
\hline \multirow[t]{2}{*}{ Análises } & \multicolumn{3}{|c|}{ Agroindústrias } & \multirow[t]{2}{*}{ Dms } \\
\hline & $A$ & $\mathrm{~B}$ & $\mathrm{C}$ & \\
\hline EST & $40,27 \pm 0,48^{b}$ & $38,98 \pm 0,19 a b$ & $36,97 \pm 0,62^{a}$ & 1,96 \\
\hline Umidade & $59,87 \pm 0,20^{a}$ & $61,20 \pm 0,26^{b}$ & $63,11 \pm 0,14 c$ & 0,22 \\
\hline Gordura & $20,50 \pm 0,70^{a}$ & $20,75 \pm 0,25^{a}$ & $19,50 \pm 0,50^{a}$ & 4,33 \\
\hline Cinzas & $2,70 \pm 0,01 \mathrm{a}$ & $3,48 \pm 0,07 b$ & $2,63 \pm 0,005^{a}$ & 0,15 \\
\hline Cloretos & $0,83 \pm 0,003$ & $1,51 \pm 0,006^{c}$ & $1,16 \pm 0,006^{b}$ & 0,01 \\
\hline Acidez & $4,6 \pm 0,002^{a}$ & $4,6 \pm 0,002^{a}$ & $6,4 \pm 0,006^{b}$ & 0,10 \\
\hline $\mathrm{pH}$ & $6,59 \pm 0,02^{c}$ & $6,39 \pm 0,02^{b}$ & $5,89 \pm 0,03^{a}$ & 0,10 \\
\hline
\end{tabular}

Letras diferentes na mesma linha indicam haver diferença significativa ao nível de $5 \%$ de significância $(p<0,05)$ pelo teste de Tukey.

Legenda: Dms: diferença mínima significativa; EST: extrato seco total; ESD: extrato seco desengordurado.

O valor de acidez encontrado nas amostras das agroindústrias $A$ e $C$ foram superiores ao padrão estabelecido $(0,14$ a 0,18$)$ pela Instrução Normativa $n^{\circ} 62$ de 29 de dezembro de 2011, uma vez que apenas as amostras de leite cru da agroindústria B estão de acordo com a legislação, sendo que as amostras da agroindústria $\mathrm{C}$ apresentaram diferença significativa quando comparadas às demais amostras. Alguns dos fatores que contribuem para a ocorrência do leite ácido são condições precárias de higiene durante e após a ordenha, utensílios mal higienizados, deficiência de refrigeração e tempo prolongado de estocagem (FREITAS et al., 2013).

O teor de proteína preconizado pela legislação é no mínimo de 2,95\%, indicando que somente as amostras da agroindústria $C$ estão em conformidade com a legislação. Sendo que todas as amostras não diferiram entre si $(p>0,05)$. $O$ baixo teor de proteína das amostras das agroindústrias $A$ e $B$ podem estar relacionados com a dieta do animal, pois segundo Schwab (1996), a utilização de forragem de boa qualidade e dietas com teores de proteína não degradáveis no rúmen e fornecimento de aminoácidos essenciais são estratégias alimentares utilizadas com o intuito de aumentar a porcentagem de proteína do leite. A proteína do leite tem sido ao longo dos últimos anos, o nutriente de maior interesse para muitos pesquisadores, uma vez que está diretamente relacionada com rendimento de derivados lácteos, o que pode aumentar a remuneração dos produtores. No entanto, a proteína do leite é um nutriente difícil de ser alterado (SIMILI; LIMA, 2007). 
Em relação ao teor de extrato seco total, cinzas e pH todas as amostras diferiram entre si $(p<0,05)$. $\mathrm{O} \mathrm{pH}$ do leite recém-ordenhado de uma vaca pode variar de 6,4 a 6,8, e também pode ser um indicador da qualidade sanitária e da estabilidade térmica do leite. Nos casos graves de mastite, o $\mathrm{pH}$ pode chegar a 7,5 e na presença de colostro, pode cair para 6,0. Como as amostras apresentaram uma variação entre 6,65 e 6,77, todas estão dentro do recomendado.

Quanto ao extrato seco desengordurado e densidade, as amostras não diferiram entre si $(p>0,05)$. As amostras das agroindústrias B e $C$ apresentaram valores maiores de umidade do que as amostras da agroindústria $A$. Valores de umidade no leite superiores a $87,5 \%$ podem indicar fraude por adição de água. Segundo Oliveira (2009), os valores considerados normais para este parâmetro podem variar entre 85 e 88 (g. $100 \mathrm{~g}$-1), desta forma, as diferenças verificadas podem ser atribuídas a alterações na composição do leite cru em virtude da influência de fatores como alimentação, estágio de lactação e raça.

Os leites da agroindústria $A$ apresentaram maior valor de gordura quando comparado com os das agroindústrias $\mathrm{B}$ e $\mathrm{C}$, que não diferiram entre si, estando todas as amostras em conformidade com a legislação vigente (mínimo 3,0\%).

As amostras da agroindústria $A$ apresentaram maior valor de cloretos que as amostras das agroindústrias $\mathrm{B}$ e $\mathrm{C}$, sendo que as últimas não diferiram entre si. De acordo com Beloti et al. (1999) que avaliaram amostras de leite cru comercializados em Cornélio Procópio-Paraná, os resultados das análises evidenciaram baixa qualidade do leite. De acordo com essa pesquisa, em relação à acidez, $61,64 \%$ das amostras estavam fora do padrão, sendo que $52,38 \% \mathrm{com}$ acidez acima de $18^{\circ} \mathrm{D}$ e $47,61 \%$ com acidez abaixo de $15^{\circ} \mathrm{D}$. A acidez elevada no leite é resultado da fermentação da lactose provocada pela multiplicação de bactérias lácticas. A acidez do leite também pode ocasionar a coagulação da caseína e assim, limitar seu uso (BJORKROTH; KOORT, 2011).

Os valores de extrato seco desengordurado, umidade e extrato seco total das amostras de leite cru analisadas apresentaram valores abaixo do recomendado pela legislação. Amaral e Santos (2011), que avaliaram o leite cru comercializado na cidade de Solânea-PB, encontraram valores de extrato seco desengordurado de todas as amostras muito abaixo do recomendado pela legislação. Todas as amostras avaliadas estavam em desacordo com a legislação em relação ao extrato seco total.

Montanhini e Heina (2013), ao avaliarem a qualidade do leite cru comercializado em uma cidade do estado do Paraná, observaram que a análise que obteve mais amostras em desacordo com a legislação foi o extrato seco desengordurado, onde $48 \%$ estavam em desacordo com a legislação vigente. Segundo esses pesquisadores, em uma das amostras foi correlacionado o menor percentual de extrato seco desengordurado com a menor densidade encontrada, o que pode levar a suspeita de adição de água que é uma prática comum no leite comercializado informalmente. Brandão et al. (2015) evidenciaram em suas colocações o acréscimo na demanda pelo leite informal produzido em Itaqui-RS, pois parte da população local opta por consumir leite não inspecionado e, muitas vezes, produzido fora dos padrões sanitários legais, que não paga impostos, em detrimento de consumir/comprar de empresas que pertencem a cadeias produtivas formais e consolidadas.

Quanto às análises microbiológicas, foram encontradas contagens de $3,2 X$ $10^{6}, 1,8 \times 10^{5}$ e $2,2 \times 10^{7} \mathrm{UFC} / \mathrm{mL}$ de aeróbios mesófilos nos leites crus das propriedades A, B e C respectivamente. Considerando o limite de $10^{5} \mathrm{UFC} / \mathrm{mL}$ de aeróbios mesófilos em leite cru refrigerado (BRASIL, 2011), todas as amostras apresentaram valores acima dos exigidos pela legislação. Em amostras de leite cru, 
Nero et al. (2005) também constataram incidência elevada (48,6\%) de amostras que apresentaram contagens de aeróbios mesófilos acima da legislação evidenciando dificuldades dos produtores em adequação às normas estabelecidas.

Pinto et al. (2006), avaliando a população de aeróbios mesófilos em amostras de leite cru provenientes de tanques individuais e coletivos, obtiveram valores de $1,4 \times 10^{6}$ a $5,5 \times 10^{6} \mathrm{UFC} / \mathrm{mL}$, acima do padrão estabelecido. Segundo esses autores, a menor variação na contagem pode estar associada à constante homogeneização do leite no silo, enquanto a maior contaminação dessas amostras pode decorrer da mistura de leite cru de diferentes origens e graus de contaminação. Além disso, deve-se considerar que podem ocorrer contaminações adicionais e crescimento microbiano durante o transporte e estocagem na agroindústria. Fato este que não deveria ocorrer com a produção de queijo artesanal, uma vez que para o processamento desses queijos, o leite recém ordenhado deverá ser utilizado no processamento desses produtos.

\subsection{Análise dos queijos artesanais}

Tabela 2 - Resultados das análises físico-químicas das amostras de queijo das diferentes propriedades rurais.

\begin{tabular}{l|lllll}
\hline \multirow{2}{*}{ Análises } & \multicolumn{3}{|c|}{ Agroindústrias } & \multirow{2}{*}{ Dms } \\
\cline { 2 - 4 } & \multicolumn{1}{|c}{$\mathrm{A}$} & \multicolumn{1}{|c}{$\mathrm{B}$} & $\mathrm{C}$ & \\
\hline EST & $40,27 \pm 0,48^{\mathrm{b}}$ & $38,98 \pm 0,19^{\mathrm{a}} \mathrm{b}$ & $36,97 \pm 0,62^{\mathrm{a}}$ & 1,96 \\
Umidade & $59,87 \pm 0,20^{\mathrm{a}}$ & $61,20 \pm 0,26^{\mathrm{b}}$ & $63,11 \pm 0,14^{\mathrm{c}}$ & 0,22 \\
Gordura & $20,50 \pm 0,70^{\mathrm{a}}$ & $20,75 \pm 0,25^{\mathrm{a}}$ & $19,50 \pm 0,50^{\mathrm{a}}$ & 4,33 \\
Cinzas & $2,70 \pm 0,01^{\mathrm{a}}$ & $3,48 \pm 0,07^{\mathrm{b}}$ & $2,63 \pm 0,005^{\mathrm{a}}$ & 0,15 \\
Cloretos & $0,83 \pm 0,003^{\mathrm{a}}$ & $1,51 \pm 0,006^{\mathrm{c}}$ & $1,16 \pm 0,006^{\mathrm{b}}$ & 0,01 \\
Acidez & $4,6 \pm 0,002^{\mathrm{a}}$ & $4,6 \pm 0,002^{\mathrm{a}}$ & $6,4 \pm 0,006^{\mathrm{b}}$ & 0,10 \\
pH & $6,59 \pm 0,02^{\mathrm{c}}$ & $6,39 \pm 0,02^{\mathrm{b}}$ & $5,89 \pm 0,03^{\mathrm{a}}$ & 0,10 \\
\hline
\end{tabular}

Letras diferentes na mesma linha indicam diferença significativa ao nível de $5 \%$ de significância $(p<0,05)$ pelo teste de Tukey.

Legenda EST: Extrato Seco Total; Dms: Diferença mínima significativa.

Houve diferença significativa entre as amostras das agroindústrias $\mathrm{A}$ e $\mathrm{C}$ em relação ao extrato seco total, sendo que a $A$ não diferiu da $B$ e esta não diferiu da $C$. As amostras de queijo das agroindústrias $A, B$ e $C$ apresentaram diferença significativa quanto ao teor de umidade, cloretos e $\mathrm{pH}$. Quanto ao teor de umidade, as amostras são classificadas como queijo de muito alta umidade, não inferior a $55,0 \%$ (BRASIL, 1996). Esse valor de umidade não atende a legislação (BRASIL, 2012), que preconiza valores de até $54 \%$ de umidade para queijo Minas Artesanal. A variação no teor de umidade do queijo pode estar associada a sua fabricação artesanal, uma vez que nas agroindústrias não há equipamentos nem utensílios industriais como tanques e lira, dificultando assim a obtenção de grãos uniformes.

Machado et al. (2004) encontraram valores elevados de cloretos em queijos artesanais do Serro, justificado pela adição manual de diferentes quantidades de sal na superfície dos queijos, podendo ser uma das causas das variações no nível de cloretos das amostras estudadas.

O teor médio de gordura no extrato seco (GES) foi de $52 \%$ classificando o queijo como gordo (BRASIL, 1996). Quanto ao teor de cinzas, as amostras da agroindústria $B$ apresentaram diferença significativa $(p<0,05)$ das amostras das agroindústrias A e C. Quanto ao teor de acidez as amostras da agroindústria $\mathrm{C}$ 
apresentaram maiores valores que as das outras. O aumento da acidez está diretamente relacionada com 0 aumento de micro-organismos mesófilos, psicotróficos e bactérias lácticas que transformam a lactose em ácido lático (JAY, 2005). Acidez excessiva pode alterar os aspectos sensoriais em queijos por produzir sabor ácido, descaracterizando o produto.

Oliveira et al. (2013), em trabalho realizado com queijos Minas artesanais produzidos em diferentes microrregiões de Minas Gerais, verificaram que aqueles produzidos na região da Canastra apresentaram características físico-químicas semelhantes, diferindo apenas quanto ao teor de gordura e cloretos em relação aos queijos das demais regiões $(p<0,05)$. Para Gomes et al. (2010), variação significativa dos valores encontrados em análises físico-químicas pode ser explicada pela falta de padronização na fabricação dos queijos pelos produtores, exemplo de queijo artesanal comercializado no mercado central de Belo Horizonte, MG.

A Tabela 3 indica a contagem de coliformes $30^{\circ} \mathrm{C}$ e $45^{\circ} \mathrm{C}$ das amostras de queijo artesanal das diferentes agroindústrias familiares.

Tabela 3 - Determinação de coliformes $30^{\circ} \mathrm{C}$ e coliformes $45^{\circ} \mathrm{C}$ das amostras de queijo.

\begin{tabular}{ccc}
\hline Agroindústrias & $\begin{array}{c}\text { Coliformes 30 } \mathrm{C} \\
(\mathrm{NMP} / \mathrm{g})\end{array}$ & $\begin{array}{c}\text { Coliformes 45ㅇ } \\
(\mathrm{NMP} / \mathrm{g})^{*}\end{array}$ \\
\hline A & $5,0 \times 10^{4}$ & $1,5 \times 10^{2}$ \\
B & $1,1 \times 10^{5}$ & $9,2 \times 10^{2}$ \\
C & $1,1 \times 10^{5}$ & $1,1 \times 10^{2}$ \\
\hline
\end{tabular}

* Limite: 5,0 x 10³ NMP.g-1 (BRASIL, 2001).

Para queijos de muito alta umidade ( $>55 \%$ ) o nível máximo preconizado é de $\leq 5,0 \times 10^{3}$ NMP.g ${ }^{1}$ para coliformes $45^{\circ} \mathrm{C}$, portanto, todas as amostras apresentaram valores de acordo com a legislação.

Foram observados valores superiores a $10^{4} \mathrm{NMP} / \mathrm{ML}$ de coliformes $30^{\circ} \mathrm{C}$. Embora a legislação não estabeleça limites de contaminação para coliformes $30^{\circ} \mathrm{C}$, sua presença em altas contagens em um alimento indica falhas higiênicas ao longo do processamento e armazenamento. Coliformes $30^{\circ} \mathrm{C}$ em números elevados podem deteriorar o produto, além de serem indicativos de condições higiênicas de produção precárias. Coliformes fecais a $45^{\circ} \mathrm{C}$ nos alimentos fornecem informações sobre as condições higiênicas do produto, isso porque fazem parte de um grupo de bactérias que habitam o trato intestinal do homem e de outros animais e contaminam 0 alimento por meio das fezes (JAY, 2005).

Coliformes como Escherichia coli e Klebsiella spp, por exemplo, são encontrados nos dejetos dos animais, no solo e em água contaminada. Altas contagens de coliformes (acima de $50 \mathrm{UFC} / \mathrm{ml}$ ) sugerem contaminação fecal de úberes e tetos sujos, deficiência na higiene da ordenha, falhas na limpeza dos equipamentos ou utilização de água contaminada na limpeza dos equipamentos (BRITO, 2010).

Bastos (2001) e Santana et al. (2008), estudando a qualidade microbiológica de queijo de coalho, relataram ocorrência de micro-organismos patogênicos e contagens de micro-organismos deterioradores em números que excedem os limites estabelecidos pela legislação. Dentre as bactérias patogênicas detectadas destacam-se Staphylococcus aureus, Salmonella ssp. e Listeria monocytogenes. 


\subsection{Avaliação das condições higiênico-sanitárias dos manipuladores e ordenadores}

Pela técnica de sedimentação simples, foram encontrados os seguintes valores de aeróbios mesófilos para o ambiente de produção das propriedades $A, B$, C e D, respectivamente: $3,2 \times 10^{2} ; 1,3 \times 10^{2} ; 1,4 \times 10^{3}$ e $6,1 \times 10^{2} \mathrm{UFC} / \mathrm{cm}^{2} / \mathrm{semana}$. Não existem padrões de legislação com relação à qualidade microbiológica de ar de ambientes. No entanto, encontram-se recomendações (APHA, 2001), que estabelece limites de $30 \mathrm{UFC} / \mathrm{cm}^{2} /$ semana para aeróbios mesófilos pela técnica de sedimentação simples. Outros pesquisadores recomendam limites para aeróbios mesófilos, bolores e leveduras pela técnica de sedimentação simples de até 100 $\mathrm{UFC} / \mathrm{cm}^{2} /$ semana. Considerando esses valores, todas as amostras de superfície de produção para a técnica de sedimentação simples não atendem a recomendação. Algumas instituições como a OPAS (Organização Pan-Americana da Saúde) e a OMS (Organização Mundial da Saúde ou de Saúde) admitem contagens de até 50 UFC/ $\mathrm{cm}^{2}$ de superfícies.

A Tabela 4 mostra os valores médios encontrados de coliformes $30^{\circ} \mathrm{C}$, coliformes $45^{\circ} \mathrm{C}$, aeróbios mesófilos e bolores e leveduras nas mãos de manipuladores e ordenhadores de diferentes propriedades rurais.

As contagens de aeróbios mesófilos, coliformes $30^{\circ} \mathrm{C}$, coliformes $45^{\circ} \mathrm{C}$ e bolores e leveduras apresentaram valores superiores nas mãos dos ordenhadores quando comparado com as mãos dos manipuladores de alimentos. Silva et al. (1997), em sua pesquisa, também verificaram que a mão do ordenhador também foi identificada como importante ponto de contaminação do leite e que parte dessa contaminação provavelmente foi incorporada aos tetos e ao leite durante a ordenha, uma vez que as mãos não eram lavadas durante a ordenha.

A qualidade do leite cru no Brasil é considerada, em geral, insatisfatória devido às altas contagens de micro-organismos aeróbios mesófilos, coliformes e psicrotróficos (SANTANA et al., 2001). Os procedimentos empregados na ordenha determinam a qualidade microbiológica do leite. Cada etapa nesse processo pode ser responsável pela inclusão de milhões de microrganismos no leite, no caso da ausência de boas práticas de higiene (SANTANA et al., 2001). O estudo dos grupos de microrganismos presentes permite determinar a origem da contaminação. 
Tabela 4 - Contagens médias de coliformes $30^{\circ} \mathrm{C}$, coliformes $45^{\circ} \mathrm{C}$, aeróbios mesófilos e bolores e leveduras nas mãos de manipuladores e ordenhadores.

\begin{tabular}{|c|c|c|c|c|}
\hline \multirow[t]{2}{*}{ Agroindústrias } & $\begin{array}{c}\text { Coliformes } \\
30^{\circ}(\mathrm{NMP} / \mathrm{mL})\end{array}$ & $\begin{array}{l}\text { Coliformes } \\
45^{\circ} \text { (NMP/ } \\
\text { mL) }\end{array}$ & $\begin{array}{l}\text { Aeróbios } \\
\text { Mesófilos } \\
\text { (UFC/mL) }\end{array}$ & $\begin{array}{c}\text { Bolores e } \\
\text { Leveduras } \\
\text { (UFC/mL) }\end{array}$ \\
\hline & \multicolumn{4}{|c|}{ Mãos do manipulador } \\
\hline A & $<3,0$ & $<3,0$ & $5,5 \times 10^{4}$ & $2,0 \times 10^{1}$ \\
\hline$B$ & $<3,0$ & $<3,0$ & $6,0 \times 10^{4}$ & $4,0 \times 10^{1}$ \\
\hline $\mathrm{C}$ & $<3,0$ & $<3,0$ & $6,0 \times 10^{4}$ & $5,0 \times 10^{1}$ \\
\hline D & $<3,0$ & $<3,0$ & $5,0 \times 10^{4}$ & $2,0 \times 10^{1}$ \\
\hline Agroindústrias & \multicolumn{4}{|c|}{ Mãos do ordenhador } \\
\hline $\mathrm{A}$ & $1,1 \times 10^{3}$ & $1,1 \times 10^{1}$ & $3,2 \times 10^{5}$ & $5,2 \times 10^{4}$ \\
\hline B & $2,4 \times 10^{2}$ & $1,5 \times 10^{1}$ & $6,0 \times 10^{5}$ & $6,0 \times 10^{3}$ \\
\hline $\mathrm{C}$ & $1,1 \times 10^{3}$ & $1,1 \times 10^{3}$ & $3,5 \times 10^{5}$ & $5,4 \times 10^{4}$ \\
\hline D & $1,1 \times 10^{3}$ & $7,5 \times 10^{2}$ & $4,0 \times 10^{5}$ & $1,0 \times 10^{1}$ \\
\hline
\end{tabular}

Segundo Andrade e Macedo (1996), as sugestões e recomendações para condições higiênicas satisfatórias de manipuladores de alimentos são: $1,2 \times 10^{4}$ UFC/mão para aeróbios mesófilos, $7,0 \times 10^{2} \mathrm{UFC/mão} \mathrm{para} \mathrm{coliformes} 30^{\circ} \mathrm{C}$ e $4,0 \times 10^{2}$ UFC/mão para bolores e leveduras. De acordo com essas recomendações para as mãos de manipulador, todas as amostras estão dentro das recomendações para coliformes $30^{\circ} \mathrm{C}$ e $45^{\circ} \mathrm{C}$. Para as análises de aeróbios mesófilos, as amostras apresentaram valores superiores ao recomendado. Para bolores e leveduras, as mãos dos manipuladores apresentaram resultados inferiores a $4,0 \times 10^{2}$, indicando boas condições higiênico-sanitárias.

Quanto às análises de coliformes, somente as mãos do ordenhador da Agroindústria $B$ encontra-se conforme a recomendação. Para os outros ordenhadores, houve valores acima do recomendado. Para aeróbios mesófilos, todas as amostras estavam acima das recomendações. $\mathrm{Na}$ análise de bolores e leveduras somente as mãos do ordenhador da Agroindústria $D$ está conforme a recomendação.

Mesquita et al. (2006) consideram que as mãos dos manipuladores, após lavagem com água e sabonete líquido, com ou sem sanificante, deve estar livre de microrganismos potencialmente patogênicos, pois, para os autores, as mãos são consideradas o principal veículo de transferência de agentes infecciosos. A higiene pessoal dos ordenhadores é outro fator importante. Pesquisadores observaram que fazendas onde os ordenhadores não lavavam as mãos durante o período de ordenha foram 7,81 vezes mais propensas a terem maior contagem de microorganismos (MOLINERI et al., 2012). 


\subsection{Avaliação das condições higiênico-sanitárias das caixas de transporte e ambiente de produção}

A Tabela 5 mostra as contagens médias de micro-organismos (UFC/cm²) de aeróbios mesófilos e bolores e leveduras da caixa de transporte e da superfície de produção das diferentes propriedades rurais.

\section{Tabela 5 - Contagens médias de micro-organismos (UFC/ $\mathrm{cm}^{2}$ ) de aeróbios mesófilos e bolores e leveduras da caixa de transporte e da superfície de produção.}

\begin{tabular}{c|c|c|c}
\multicolumn{3}{c}{ Aeróbios Mesófilos } & \multicolumn{2}{c}{ Bolores e leveduras } \\
\hline Agroindústrias & $\begin{array}{c}\text { Swab superfície } \\
\text { de produção } \\
\left(\mathrm{UFC} / \mathrm{cm}^{2}\right)\end{array}$ & $\begin{array}{c}\text { Caixa de } \\
\text { transporte } \\
\left(\mathrm{UFC} / \mathrm{cm}^{2}\right)\end{array}$ & $\begin{array}{c}\text { Superfície de } \\
\text { produção } \\
\left(\mathrm{UFC} / \mathrm{cm}^{2}\right)\end{array}$ \\
\hline A & $3,2 \times 10^{2}$ & $1,0 \times 10^{1}$ & $1,0 \times 10^{1}$ \\
B & $1,3 \times 10^{2}$ & $6,0 \times 10^{1}$ & $5,5 \times 10^{1}$ \\
C & $1,4 \times 10^{3}$ & $9,7 \times 10^{1}$ & $1,3 \times 10^{2}$ \\
D & $6,1 \times 10^{2}$ & $2,0 \times 10^{1}$ & $1,0 \times 10^{1}$ \\
\hline
\end{tabular}

Segundo a APHA (2001), para equipamentos e utensílios utilizados em indústrias processadoras de alimentos, é recomendado uma contagem máxima de 2,0 UFC/ $\mathrm{cm}^{2}$ para aeróbios mesófilos. Considerando esse limite para os microorganismos avaliados, somente a caixa de transporte da agroindústria $A$, para a contagem de aeróbios mesófilos, encontra-se conforme a recomendação.

Algumas instituições como a Organização Panamericana de Saúde (OPAS) e a Organização Mundial da Saúde (OMS) admitem contagens de até $50 \mathrm{UFC} / \mathrm{cm}^{2}$ para aeróbios mesófilos em superfícies (ANDRADE, 2008). Com essas recomendações para aeróbios mesófilos somente a caixa de transporte da agroindústria A atende a essa especificação. Para bolores e leveduras, as superfícies avaliadas das agroindústrias $A$ e $D$ atendem a essa recomendação, indicando melhores condições higiênicas que os estabelecimentos $\mathrm{B}$ e $\mathrm{C}$, em relação a esses microrganismos.

Peixoto et al. (2012), avaliando os níveis de contaminação microbiológica do ambiente de laticínios artesanais da região do agreste paraibano, verificaram que quanto à contaminação do ar, tanto para bactérias mesófilas aeróbias quanto para bolores e leveduras, ocorreu diferença significativa entre os ambientes. Isso se deve, provavelmente, ao sistema de produção desses ambientes. Mesmo havendo semelhança no interior de cada uma das queijarias, existe a influência dos fatores externos, como a proximidade das instalações zootécnicas (aves, suínos e bovinos).

Silva et al. (2011), ao avaliarem equipamentos e utensílios utilizados em laticínios da região de Rio Pomba, MG, verificaram condições higiênicas inadequadas, podendo ser focos de contaminação. Peixoto et al. (2012) observaram que o Penicillium é um dos principais gêneros de bolores e leveduras presentes no leite, no queijo, na superfície e no ambiente de queijarias. 


\section{CONCLUSÕES}

Com este estudo se conclui que algumas amostras de leite cru avaliadas estavam fora dos parâmetros estabelecidos pela legislação vigente, o que pode comprometer a qualidade do produto final. Com as análises físico-químicas dos produtos pode-se verificar que há variação entre as amostras, provavelmente devido a tecnologia de fabricação adotada por cada agroindústria familiar. Como os resultados indicam que um dos maiores problemas de contaminação esteve na ordenha, é necessário que os ordenhadores sejam treinados e conscientizados da importância das Boas Práticas de Fabricação. As análises microbiológicas demonstraram a má qualidade higiênico-sanitária dos produtos e a necessidade de efetiva fiscalização pelos órgãos competentes, uma vez que esses queijos podem propiciar a ocorrência de doenças transmitidas por alimentos.

Estudos adicionais são necessários no intuito de se avaliar a qualidade microbiológica do queijo Minas artesanal em diferentes períodos de maturação, de modo que se possa determinar o adequado período de maturação para esses queijos, considerando-se aspectos regionais como temperatura e umidade, para garantir assim a saúde do consumidor.

\section{REFERÊNCIAS}

AMARAL, C. R. S.; SANTOS, E. P. Leite cru comercializado na cidade de Solânea, PB: caracterização físico-química e microbiológica. Revista Brasileira de Produtos Agroindustriais, v. 13, n. 1, p. 7-13, 2011.

ANDRADE, N. J. Higiene na indústria de alimentos: avaliação e controle da adesão e formação de biofilmes bacterianos. São Paulo: Editora Varela, 2008.

ANDRADE, N. J; MACEDO, J. A. B. Higienização na indústria de alimentos. São Paulo: Editora Varela, 1996.

APHA. American Public Health Association. For the examination of dairy products, 17. ed. Editora: Robert T. Marshall. 2001.

BASTOS, M. do S. R.; NASSU, R. T.; BORGES, M. de F.; SILVA, J. B. Inspeção em uma indústria produtora de queijo tipo coalho o estado do Ceará, visando a implantação das boas práticas de fabricação. Revista do Instituto de Laticínios Cândido Tostes, v. 57, p. 130-136, 2001.

BELOTI, V.; BARROS, M. A. F.; SOUZA, J. A.; SANTANA, E. H. W.; BALARIN, O.; CURIAKI, Y. Avaliação da qualidade do leite cru comercializado em Cornélio Procópio, Paraná: controle de consumo e da comercialização. Semina: Ciências Agrárias, v. 20, n. 1, p. 12-15, 1999.

BJORKROTH, J.; KOORT, J. Lactic acid bactéria: taxonomy and biodiversity. In: John FUQUAY, W.; FOX, P. F.; MCSWEENEY, P. L. H (ed.). Encyclopedia of Dairy Science. 2. ed. London: Elsevier, 2011. v. 1, p. 45-48.

BRANDÃO, J. B., BREITENBACH, R., DIAS, V. S., SILVA, B. B. Leite clandestino: a informalidade orientada pela demanda - Um diagnóstico da produção e comercialização em Itaqui/Rio Grande do Sul. Extensão Rural, v. 22, n. 2, p. 113131, 2015. 
BRASIL. Ministério da Agricultura Pecuária e Abastecimento. Instrução Normativa n. 30, de 07 de Agosto de 2013. Diário Oficial da União. Brasília, DF, 08/08/2013.

BRASIL. Minas Gerais. Lei no 20549, de 18 de dezembro de 2012. Dispõe sobre a produção e a comercialização dos queijos artesanais de Minas Gerais.

BRASIL. Ministério da Agricultura Pecuária e Abastecimento. Departamento de Inspeção de Produtos de Origem Animal. Instrução Normativa n. 62, de 26 de agosto de 2006. Diário Oficial da União. Brasília, DF, 2003.

BRASIL. Ministério da Agricultura, Pecuária e Abastecimento. Instrução Normativa nº 68, de 12 de dezembro de 2006. Métodos Analíticos oficiais físico-químicos, para controle de leite e produtos lácteos. Diário Oficial da União, Brasília, v. Seção 1, p. 8, 2006.

BRASIL. Ministério da Agricultura, Pecuária e Abastecimento. Instrução Normativa no 62, de 29 de dezembro de 2011. Regulamento Técnico de Produção, Identidade e Qualidade do Leite tipo A, Regulamento Técnico de Identidade e Qualidade de Leite Cru Refrigerado, o Regulamento Técnico de Identidade e Qualidade de Leite Pasteurizado e o Regulamento Técnico da Coleta de Leite Cru Refrigerado e seu Transporte a Granel. Brasília. MAPA, 2011.

BRASIL. Portaria no 146, de 07 de março de 1996. Ministério da Agricultura e do Abastecimento. Secretaria Nacional de Inspeção de Produtos de Origem Animal. Regulamentos Técnicos de Identidade e Qualidade dos Produtos Lácteos. Diário Oficial da União, Brasília, mar. 1996.

BRASIL. Resolução n. 7, de 28 de novembro de 2000. Critérios de Funcionamento e de Controle da Produção de Queijarias, para seu relacionamento junto ao Serviço de Inspeção Federal. Ministério da Agricultura e do Abastecimento. Secretaria Nacional de Inspeção de Produtos de Origem Animal. Diário Oficial da União, Brasília, DF, 2 de janeiro de 2001.

BRITO, M. A. V. P.; BRITO, J. R. F.; PORTUGAL, J. A. B. Identificação de contaminantes bacterianos no leite cru de tanques de refrigeração. Revista do Instituto de Laticínios Cândido Tostes, v. 57, n. 327, p. 83-88, 2010.

CÂMARA, S. A. V.; AMARAL, G. B.; MULLER, M. T.; SILVEIRA, K. C. S.; ALMEIDA, T. N.; MEDEIRO, C. F. Avaliação microbiológica de queijo tipo minas frescal artesanal, comercializados no mercado municipal de Campo Grande, Mato Grosso do Sul. Revista Higiene Alimentar. v. 16, n. 101, p. 32-36, 2000.

EMATER-MG. 8 Concurso Regional do Queijo Minas Artesanal Araxá. Disponível em: http://www.emater.mg.gov.br/portal. Acesso em maio de 2014.

FERREIRA, D. F. Sisvar versão 4.2. DEX/UFLA, 2003

FREITAS, W. C; TRAVASSOS, A. E. R; MACIEL, J. F. Avaliação microbiológica e físico-química de leite cru e queijo de coalho produzidos no estado da Paraíba. Revista Brasileira de Produtos Agroindustriais, v. 15, n. 1, p. 35-42, 2013. 
GOMES, F. C. O.; ROSA, C. A.; SILVA, C. L. C.; WALTER, M. E.; Avaliação microbiológica, físico-química e sensorial de amostras de queijo minas artesanal, comercializadas em mercado público de Belo Horizonte, MG. Revista Higiene Alimentar, v. 24, n. 192/193. p. 97-101, 2010.

IBGE, $2014 . \quad$ Disponível em: http://www.cidades.ibge.gov.br/xtras/perfil.php?lang=\&codmun=316850\&search=min as-gerais|teixeiras. Acesso em: 10 de outubro de 2014.

IMA. Agroindústria Familiar. Disponível em: www.ima.mg.gov/agroindustria-familiar. Acesso em maio 2014.

JAY, J. M. Microbiologia de alimentos, 6. ed. Porto Alegre: Artmed, 2005.

LEI ESTADUAL/MG n. 14.185, de 31 de janeiro de 2002. Dispõe sobre o processo de produção do Queijo Minas Artesanal e dá Outras Providências. Belo Horizonte, 2002.

MACHADO, E. C.; FERREIRA, C. L. L. F.; FONSECA, L. M.; SOARES, F. M.; PEREIRA JUNIOR, F. N. Características físico-químicas e sensoriais do queijo Minas Artesanal produzido na região do Serro, Minas Gerais. Ciência e Tecnologia em Alimentos, v. 24, p. 516-521. 2004.

MATTOS, C. A. C.; SANTANA, A. C. As contribuições da pecuária leiteira para os agricultores familiares: um estudo no sudeste do estado do Pará. Extensão Rural, v. 20, n. 1, p. 56-71, 2014.

MESQUITA, M. O.; DANIEL, A. P.; SACCOL, A. L. F.; MILANI, L. I. G.; FRIES, L. L. M. Qualidade microbiológica no processamento de frango assado em unidades de alimentação e nutrição. Ciência e Tecnologia de Alimentos, v. 26, n. 1, p. 198-203, 2006.

MOLINERI, A. L.; SIGNORINI, M. L.; CUATRÍN, A. L.; CANAVESIO, V. R.; NEDER, V. E.; RUSSI, N. B.; BONAZZA, J. C.; CALVINHO, L. F. Association between milking practices and psychrotrophic bacterial counts in bulk tank milk. Revista Argentina de Microbiologia, v. 44, p. 187-194, 2012.

MONTANHINI, M. T. Z; HEIN K. K. Qualidade do leite cru comercializado informalmente no município de piraí do Sul, estado do Paraná, Brasil. Revista do Instituto de Laticínios Cândido Tostes, v. 68, n. 393, p. 10-14, 2013.

NERO, L. A.; MATTOS, M. R.; BELOT, V.; BARROS, M. A. F.; PINTO; J. P. A. N.; ANDRADE, N. J.; SILVA, W. P.; FRANCO, B. D. G. M. Leite cru de quatro regiões leiteiras brasileiras: perspectivas de atendimento dos requisitos microbiológicos estabelecidos pela Instrução Normativa 51. Ciência e Tecnologia de Alimentos, v. 25, n. 1, p. 191-195, 2005.

OLIVEIRA, D. F.; PORTO, M. A. C.; BRAVO, C. E. C.; TONIAL, I. B. Caracterização físico-química de queijos Minas Artesanal produzidos em diferentes microrregiões de Minas Gerais. Revista Brasileira de Economia Doméstica, v. 24, n. 2, p. 185-196, 2013. 
OLIVEIRA, M. N. Tecnologia de produtos lácteos funcionais. São Paulo: Atheneu; 2009.

PEIXOTO, J. P. N.; NASCIMENTO, J. W. B.; FURTADO, A. F.; OLIVEIRA, C. J. B.; GOMES, J. P. Qualidade do ambiente e níveis de contaminação por microorganismos em queijarias, no agreste paraibano. Revista Brasileira de Produtos Agroindustriais, v. 14, n. 2, p. 177-183, 2012.

PINTO, C. L. O. ; MARTINS, M. L.; VANETTI, M. C. D. Qualidade microbiológica deleite cru refrigerado e isolamento de bactérias psicrotróficas proteolíticas. Ciência e Tecnologia de Alimentos, v. 26, n. 3, p. 645-651, 2006.

SANTANA, R. F.; SANTOS, D. M.; MARTINEZ, A. C. C.; LIMA, A. S. Qualidade microbiológica do queijo-coalho comercializado em Aracaju, SE. Arquivo Brasileiro de Medicina Veterinária e Zootecnia, v. 60, n. 6, 2008.

SANTANA, E. H. W.; BELOTI, V.; BARROS, M. A. F. Microrganismos psicrotróficos em leite. Higiene Alimentar, v. 15, p. 27-33, 2001.

SCHWAB, C. G. Rumen protected amino acids for dairy cattle: progress towards determining lysine and methionine requirements. Animal Feed Science Technology, v. 59, p. 87-101, 1996.

SILVA, N. B. N.; CHAVES, K. F.; GRAVINA, C. S.; MENDES, A. C. G.; MARTINS, A. D. O.; MARTINS, M. L. Avaliação microbiológica de equipamentos e Utensílios utilizados em laticínios da região de Rio Pomba - MG, Revista do Instituto de Laticínios Cândido Tostes, v. 66, n. 378, p. 5-10, 2011.

SIMILI, F. F.; LIMA, L. M. P. Como os alimentos podem afetar a composição de leite de vacas. Pesquisa \& Tecnologia, v. 4, n. 1, 2007.

SILVA, P. H. F; PEREIRA, D. B. C; OLIVEIRA, L. L; JÚNIOR, L. C. G. C. Livro físico-química do leite e derivados:métodos analíticos. Juiz de Fora: Editora UFJF. 1997.

SIQUEIRA, H. M.; LACERDA, M. G. F.; RODRIGUES, R.; BIANCARDI, C. C. S. Comercialização solidária da produção familiar de alimentos em Alegre-ES. Extensão Rural, v. 21, n. 3, p. 98-118, 2013.

SOARES, J. C. V.; SILVEIRA, V. C. T.; FIALHO, M. A. V. A crise e o recrudescimento da cadeia produtiva do leite na região noroeste/RS a partir da década de 90 e políticas agrícolas - possíveis relações. Extensão Rural, Ano XVII, n. 19, p. 135159, 2010.

SOUZA, J. B. L. Agricultura familiar e pecuária leiteira: um estudo dos assentamentos nos municípios de Peabirú e Quinta do Sol. Universidade Estadual de Maringá. Centro de ciências sociais aplicadas. Programa de pósgraduação em economia. Maringá-PR, 2010. 